Review

\title{
The Sound of Silence: RNAi in Poly (ADP-Ribose) Research
}

\section{Christian Blenn $^{\dagger}$, Philippe Wyrsch ${ }^{\dagger}$ and Felix R. Althaus *}

Institute of Pharmacology and Toxicology, University of Zurich-Vetsuisse, Winterthurerstrasse 260, 8057 Zurich, Switzerland; E-Mails: christian.blenn@vetpharm.uzh.ch (C.B.); philippe.wyrsch@vetpharm.uzh.ch (P.W.)

$\dagger$ These authors contributed equally to this work.

* Author to whom correspondence should be addressed; E-Mail: felix.althaus@vetpharm.uzh.ch; Tel.: +41-44-635-87-62; Fax: +41-44-635-89-10.

Received: 4 September 2012; in revised form: 5 November 2012 / Accepted: 6 November 2012 / Published: 6 December 2012

\begin{abstract}
Poly(ADP-ribosyl)-ation is a nonprotein posttranslational modification of proteins and plays an integral part in cell physiology and pathology. The metabolism of poly(ADP-ribose) (PAR) is regulated by its synthesis by poly(ADP-ribose) polymerases (PARPs) and on the catabolic side by poly(ADP-ribose) glycohydrolase (PARG). PARPs convert $\mathrm{NAD}^{+}$molecules into PAR chains that interact covalently or noncovalently with target proteins and thereby modify their structure and functions. PAR synthesis is activated when PARP1 and PARP2 bind to DNA breaks and these two enzymes account for almost all PAR formation after genotoxic stress. PARG cleaves PAR molecules into free PAR and finally ADP-ribose (ADPR) moieties, both acting as messengers in cellular stress signaling. In this review, we discuss the potential of RNAi to manipulate the levels of PARPs and PARG, and consequently those of PAR and ADPR, and compare the results with those obtained after genetic or chemical disruption.
\end{abstract}

Keywords: ADPR; PAR; PARP1; PARP2; PARG; siRNA

\section{The Life Cycle of Poly (ADP-Ribose)}

Poly(ADP-ribosyl)-ation belongs to the nonprotein posttranslational modifications and is a metabolite of the enzymatic cofactor nicotinamide adenine dinucleotide (NAD ${ }^{+}$). Poly (ADP-ribose) polymerases (PARPs) cleave the nicotinic moiety from $\mathrm{NAD}^{+}$and convert the ADP-ribose (ADPR) 
units into long APD-ribose polymers (PAR). At the protein level, the $\beta$ - $\alpha$-loop- $\beta-\alpha \mathrm{NAD}^{+}$fold is the most conserved region in PARPs and is therefore termed the PARP signature motif [1-3]. To date, 17 distinct PARP enzymes have been discovered and numbered accordingly. Recently a new nomenclature has been suggested that is based on their transferase activity (ARTD nomenclature [4]): PARP1 (ARTD1), PARP2 (ARTD2), PARP3 (ARTD3), PARP4 (ARTD4, vault-PARP), PARP5A (ARTD5, Tankyrase 1), PARP5B (ARTD6, Tankyrase 2), PARP6 (ARTD17), PARP7 (ARTD14, TIPARP, RM1), PARP8 (ARTD16), PARP9 (ARTD9, BAL1), PARP10 (ARTD10), PARP11 (ARTD11), PARP12 (ARTD12, ZH3HDC1), PARP13 (ARTD13, ZC3HAV1, ZAP1), PARP14 (ARTD8, BAL2 COAST6), PARP15 (ARTD7, BAL3), and PARP16 (ARTD15). However, not all PARP enzymes are proven poly(ADP-ribose) polymerases. Several of them seem to belong to the class of mono(ADP-ribosyl) transferases [5]. The nuclear PARP1 and PARP2 are the best characterized PARPs in mammals and are true poly(ADP-ribose) polymerases. PARP1 has a modular structure and starts its catalytic activity after binding to DNA nicks and breaks with the double zinc finger domain [2]. Recently, a third zinc finger-like structure was discovered. It is required for transmitting DNA-induced conformational changes to the catalytic domain [6,7]. The C-terminal catalytic domain sequentially transfers ADPR units from $\mathrm{NAD}^{+}$to protein acceptors generating PAR. Third, in the automodification domain, specific glutamatic acid and lysine residues serve as acceptors of ADPR allowing the enzyme to poly(ADP-ribosyl)ate itself. While the level of PAR is very low under physiological condition, it rises 200-fold under genotoxic stress conditions. After DNA damage, PARP1 is rapidly recruited and its catalytic activity increases 10 - to 500-fold to synthesize long and branched PAR chains (Figure 1) [3,8]. PARP1 is the main enzyme generating PAR and it is the main acceptor for covalent PAR modification. More than 90\% of PAR originates from PARP1 during genotoxic stress [8,9]. PARP-bound PAR can recruit many other proteins involved in distinct cellular functions, including enzymes involved in DNA repair [10-16]. The system of PAR accepting and/or interacting proteins is very complex and not completely understood. Moreover, novel proteome-wide analyses allow the identification of putative PAR binding proteins [10]. Automodification of PARP1 diminishes the affinity of the enzyme for DNA breaks. This provides a mechanism for removing PARP1 from damaged DNA and for local modulation of chromatin compaction and transcriptional regulation [11,17-19].

Apart from PARP1, PARP2 is activated by DNA strand breaks, as well [20,21]. The DNA-binding domain (DBD) of PARP2 is structurally different from that of PARP1 [20,22]. PARP2 binds less efficiently to DNA single-strand breaks (SSB) than PARP1 but it detects gap and flap structures [23]. PARP2 consumes less $\mathrm{NAD}^{+}$compared to PARP1 due to its less efficient PAR synthesis [20]. It contributes only $5 \%-10 \%$ of the total PARP activity in response to DNA interruptions [20,24].

The enzymatic product of PARP1 and PARP2 activity PAR comprises a heterogeneous pool of negatively charged molecules that differ in length and branching. It is noteworthy that the hyperactivation of PARP1 and PARP2, due to genotoxic stress, consumes most of the $\mathrm{NAD}^{+}$in a cell [25]. Free or protein-associated PAR, synthesized after a genotoxic insult, are rapidly degraded in vivo with a half-life of less than $40 \mathrm{sec}$, while the residual fraction is catabolized with a half-life of 6 min [26-28]. The degradation of PAR is catalyzed by PARG (PAR glycohydrolase), an enzyme with both endo- and exoglycosidic activities that hydrolyze the glycosidic bond between ADPR units. PARG produces primarily monomeric ADPR via exoglycosidic activity, albeit a few free PAR 
polymers may arise from endoglycosic cleavage (Figure 1) [29,30]. In addition, PARG displays less activity towards branched or short PAR $\left(\mathrm{K}_{\mathrm{M}} \approx 10 \mu \mathrm{M}\right)$ compared with long and linear PAR molecules $\left(\mathrm{K}_{\mathrm{M}} \approx 0.1-0.4 \mu \mathrm{M}\right)$ [29-34]. PARG is encoded by a single gene in mammals, and several splicing products are formed after transcription. They are translated into proteins of different molecular size, subcellular localization and the ability to cleave PAR. The nuclear mPARG-110/hPARG-111 isoform represents the full-length PARG protein in mice and humans and accounts for most of the PARG activity [35]. Recently another PAR-degrading enzyme has been described. The ADPR hydrolase 3 (ARH3) is structurally not related to PARG and is less efficient. Nevertheless, it provides PARdegrading activity in vitro and in PAR-enriched mitochondria, as it has been demonstrated in a PARP overexpression system [36-38].

Figure 1. Poly(ADP-ribose) metabolism. Single-strand and double-strand breaks (SSB and DSB) in the DNA are induced by genotoxic stress (1). The nuclear PARPs bind to the damaged site and are thereby activated and produce ramified and highly negatively charged poly(ADPribose) (PAR) (2). They hydrolyze NAD ${ }^{+}$, releasing nicotinamide (Nam) and $\mathrm{H}^{+}$, catalyzing the successive transfer of ADPR to acceptors (Prot) (3). PARG is the catabolic enzyme with endo- and exoglycosidic activity (4). Its hydrolyzing activity leads to either free PAR chains (5) and/or monomeric ADPR (6).

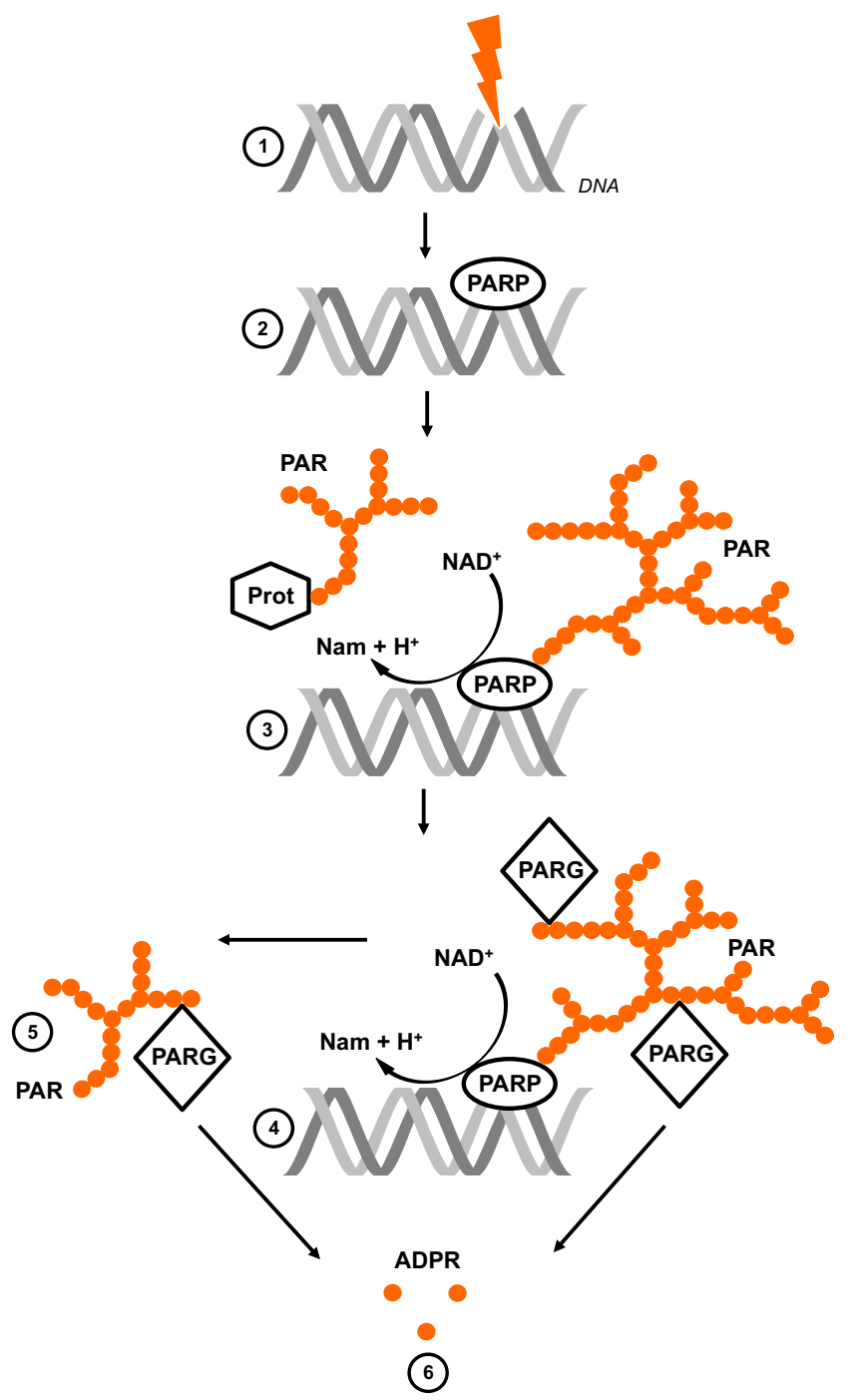


The two products of PARP/PARG interplay have been identified to exhibit different cellular signaling functions. The manipulation of either PARP or PARG activity modifies the occurrence of PAR and ADPR after genotoxic stress (Figure 1). This allows the study of distinct PAR and ADPR functions. Here, we discuss approaches to interfere with PAR metabolism to clarify the biological role of this nonprotein posttranslational modification (PAR) and its degradation product (ADPR).

\section{Experimental Tools to Investigate PAR and ADPR}

\subsection{Chemical Inhibition of PAR Metabolizing Enzymes}

Within the last few decades, the concept of interfering with proteins involved in DNA repair and stress signaling has attracted a lot of attention in both basic and clinical research. To date, chemical inhibitors against PARP enzymes have reached the first level of clinical application. Almost all PARP inhibitors in preclinical and clinical studies compete with the substrate $\mathrm{NAD}^{+}$for the catalytic domain leading to a reversible inhibition of enzyme activity. The third generation PARP inhibitors veliparib (ABT-888) and olaparib (AZD2281/KU-0059436) are the most clinically investigated, and their half-maximal inhibitory concentration $\left(\mathrm{EC}_{50}\right.$ or $\left.\mathrm{K}_{\mathrm{i}}\right)$ is in the nanomolar range for PARP1 and PARP2 (Figure 2) [39,40]. Both inhibitors are sufficiently bioavailable when administered orally and they are primarily used as anticancer drugs alone or in combination with other treatments (discussed in [41]). Moreover, the potential of PARP inhibitors to participate in the concept of synthetic lethality is under investigation $[41,42]$.

The PARP inhibitors 3-Aminobenzamide (3-AB) [25,43-45], 1,5,7,8-Tetrahydro-2-methyl-4Hthiopyrano[4,3- $d]$ pyrimidin-4-one (DR2313) [25,46], $\quad N$-(6-Oxo-5,6-dihydrophenanthridin-2-yl)( $N, N$-dimethylamino)acetamide (PJ-34) [25,47-50], 8-Hydroxy-2-methylquinazoline-4-one (NU1025) [51-53], and 3,4-Dihydro-5-[4-(1-piperidinyl)butoxyl]-1(2H)-isoquinolinone (DPQ) [54-57], were extensively used to suppress PARP activity in vitro, in cells and animals (Figure 2). They share the potential to interfere with both PAR-synthesizing enzymes activated by DNA damage due to the homology in the catalytic domain of PARP1 and PARP2, albeit with different kinetics. To overcome this problem, Moroni and co-workers developed a set of specific PARP2 inhibitors [58]. Beside synthetic PARP inhibitors, a panel of naturally occurring molecules was discovered that have PARPsuppressing activity. These compounds cover such different chemical structures as tryptophan derivatives, purines, xanthins, vitamins, hormones and metals [59].

Much less is known about the inhibitors of PARG, as was recently reviewed [60]. Whereas a number of natural and synthetic molecules have been described to exhibit PARG-suppressing activity, most of them are restricted in terms of bioavailability and/or specificity. Nevertheless, the use of Adenosine 5'-diphosphate (hydroxymethyl) pyrrolidinediol (ADP-HPD) [61,62], 3-Galloyl- $\alpha, \beta$-D-glucose [63], (Z)-3-(5-(5-Bromo-1-(2,6-dichlorobenzyl)-2-oxoindolin-3-ylidene)-4-oxo-2thioxo-thiazolidin-3-yl) propanoic acid [64], and 3,5-Dichloro- $N$-(3-chloro-4-(naphtalen-2-yloxy)phenyl)-2hydroxy benzamide [65] may inhibit PARG specifically and help understand its role within a wider biological context (Figure 3). 
Figure 2. PARP inhibitors.<smiles>NC(=O)c1cccc(N)c1</smiles><smiles>Cc1nc2c(O)cccc2c(=O)[nH]1</smiles><smiles>CC1(c2nc3c(C(N)=O)cccc3[nH]2)CCCN1</smiles><smiles>Cc1nc(=O)c2c([nH]1)CCSC2</smiles><smiles>O=C1NNC(Cc2ccc(C(=O)N3CCN(C(=O)C4CC4)CC3)c(F)c2)c2ccccc21</smiles><smiles>CN(C)CC(=O)Nc1ccc2[nH]c(=O)c3ccccc3c2c1</smiles><smiles>O=C1NCC(OCCCCN2CCCCC2)c2ccccc21</smiles>

\begin{tabular}{|c|c|c|c|}
\hline Drug name & IUPAC name & $\mathrm{IC}_{50} / \mathrm{EC}_{50}$ & Reference \\
\hline $3-\mathrm{AB}$ & 3-Aminobenzamide & $3.3 \mu \mathrm{M}\left(\mathrm{IC}_{50}\right)$ & [43] \\
\hline $\begin{array}{l}\text { ABT-888 } \\
\text { (Veliparib) }\end{array}$ & $\begin{array}{l}\text { 2-((R)-2-Methylpyrrolidin-2-yl)-1H-benzimidazole-4- } \\
\text { carboxamide }\end{array}$ & $2 \mathrm{nM}\left(\mathrm{EC}_{50}\right)$ & [40] \\
\hline $\begin{array}{l}\text { AZD-2281 } \\
\text { (Olaparib) }\end{array}$ & $\begin{array}{l}\text { 4-[(3-[(4-Cyclopropylcarbonyl)piperazin-4-yl] carbonyl)- } \\
\text { 4-fluorophenyl]methyl(2H)phthalazin-1-one }\end{array}$ & $\begin{array}{c}1-5 \mathrm{nM} \\
\left(\mathrm{IC}_{50}\right)\end{array}$ & [39] \\
\hline DPQ & $\begin{array}{l}\text { 3,4-Dihydro-5-[4-(1-piperidinyl)butoxyl]-1(2H)- } \\
\text { isoquinolinone }\end{array}$ & $40 \mathrm{nM}\left(\mathrm{IC}_{50}\right)$ & [54] \\
\hline DR2313 & $\begin{array}{l}1,5,7,8 \text {-Tetrahydro-2-methyl- } 4 H \text {-thiopyrano }[4,3-d] \\
\text { pyrimidin-4-one }\end{array}$ & $0.2 \mu \mathrm{M}\left(\mathrm{IC}_{50}\right)$ & [46] \\
\hline NU1025 & 8-Hydroxy-2-methylquinazoline-4-one & $0.4 \mu \mathrm{M}\left(\mathrm{IC}_{50}\right)$ & [51] \\
\hline PJ-34 & $\begin{array}{l}N \text {-(6-Oxo-5,6-dihydrophenanthridin-2-yl)-(N,N- } \\
\text { dimethylamino)acetamide }\end{array}$ & $20 \mathrm{nM}\left(\mathrm{EC}_{50}\right)$ & [49] \\
\hline ADP-HPD & Adenosine 5'-diphosphate (hydroxymethyl) pyrrolidinediol & 0.12 & [61] \\
\hline $\begin{array}{l}\text { Mono-galloyl } \\
\text { glucose }\end{array}$ & 3-galloyl- $\alpha, \beta$-D-glucose & $0.95 \pm 0.02$ & [63] \\
\hline RBPI-2 & $\begin{array}{l}\text { (Z)-3-(5-(5-Bromo-1-(2,6-dichlorobenzyl)-2-oxo-indolin- } \\
\text { 3-ylidene)-4-oxo-2-thioxothiazo-lidin-3-yl) propanoic acid }\end{array}$ & $2.9 \pm 1.8$ & [64] \\
\hline Salicylanilide & $\begin{array}{l}\text { 3,5-Dichloro- } N \text {-(3-chloro-4-(naphtalen-2-yloxy) phenyl)- } \\
\text { 2-hydroxybenzamide }\end{array}$ & $12 \pm 2$ & [65] \\
\hline
\end{tabular}


Figure 3. PARG inhibitors.<smiles>Nc1ncnc2c1ncn2[C@@H]1O[C@H](COP(=O)([O-])OP(=O)([O-])OCC2NC[C@@H](O)C2O)C(O)[C@H]1O</smiles>

\section{Common Name}

\section{IUPAC Name}

$\mathrm{IC}_{50}[\mu \mathrm{M}]$

Reference

ADP-HPD

Adenosine 5'-diphosphate (hydroxymethyl)

0.12

[61] pyrrolidinediol

Mono-galloyl glucose

3-galloyl- $\alpha, \beta$-D-glucose

$0.95 \pm 0.02$

RBPI-2

(Z)-3-(5-(5-Bromo-1-(2,6-dichlorobenzyl)-2-oxo-

$2.9 \pm 1.8$

indolin-3-ylidene)-4-oxo-2-thioxothiazo-lidin-3-yl)

propanoic acid

Salicylanilide

3,5-Dichloro- $N$-(3-chloro-4-(naphtalen-2-yloxy)

$12 \pm 2$ phenyl)-2-hydroxybenzamide

\subsection{Genetic Disruption of PARPs and PARG}

In the mid-1990s, the first PARP knock out (k.o.) mice were created to provide more detailed and specific information about the physiological role of PARP enzymes in different cellular responses. Wang et al. generated in 1995 a PARP1 k.o. mouse line by interrupting exon 2 [66]. The existence of these mice suggested initially that PARP1 is dispensable during embryogenesis. These mice were fertile, obviously healthy and revealed no dramatic phenotype. However, isolated cells derived from Parp $^{-/-}$mice had a marginally lower proliferation rate unrelated to DNA damage. Nevertheless, there 
was an unusual and unexpected development of skin hyperplasia in around $1 / 3$ of mice related to progressive aging. The observed skin abnormalities included thickening of all layers of the epidermis, active proliferation of keratinocytes, development of intracellular edema and an inflammatory response [66]. As 70\% of these mice remained free of any skin problems, a correlation between this phenotype and the absence of PARP1 seemed unlikely. Ménissier de Murcia et al. developed a second Parp $^{-/-}$mouse strain using a different ablation strategy by interrupting exon 4 [67], which was completely free of any skin pathologies as discussed in more detail by Rhun et al. [68]. These PARP1 k.o. mice exhibited an extreme sensitivity to whole body $\gamma$-radiation, indicating a functional link between PARP1 and DNA stress. This first report was later confirmed by Wang et al. investigating their first Parp $^{-/-}$mouse type [69]. Additionally, Ménissier de Murcia and colleagues showed that the whole body exposure to 8 Gy resulted in a very short half-life of four days with a complete lethality after eight days, compared to 50\% lethality observed in control mice (14-20 days). Dramatic lethality with extensive necrosis occurred in the epithelial lining of the small intestine [67]. Furthermore, high sensitivity to intra-peritoneal administration of $75 \mathrm{mg} / \mathrm{kg}$ of body weight of the alkylating agent $\mathrm{N}$ methyl- $N$-nitrosourea (MNU) was observed. They determined $80 \%$ lethality within the first week in Parp $^{-/-}$mice compared to $40 \%$ for control mice until week eight.

Results obtained in these two different Parpl $^{-/-}$mice lines demonstrated the involvement of PARP1 in processing genotoxic attacks. Both authors concluded that the lack of the Parpl gene led to an impaired DNA repair capacity, an accumulation of DNA strand breaks and, subsequently, high genomic instability. The results of the k.o. experiments performed by Wang et al. and Ménissier de Murcia et al. are summarized in Table 1. None of the approaches to diminish the Parpl gene resulted in the expression of fully functional truncates. However, Wang et al. reported a truncated $1.2 \mathrm{~kb}$ transcript generating a PARP1 fragment but without any enzymatic activity.

In 1999, a partial functional redundancy between PARP1 and PARP2 was observed by Amé et al. [20]. As a logical consequence, mice lacking PARP2 were needed. Therefore, Ménissier de Murcia and coworkers generated the first Parp $2^{-/-}$mice line by disrupting exon 9 [70]. These manipulated mice were fertile and viable like the Parp $^{-/-}$mice. Interestingly, they showed an even higher sensitivity to genotoxic challenges than their Parpl $^{-/}$counterparts. Moreover, Parp $2^{-/-}$mice displayed abnormalities in spermiogenesis caused by delayed nuclear elongation. They developed lipodystrophy characterized by adipodegeneration, as well as derailed differentiation of preadipocytes to adipocytes. It was also reported that genetic depletion of $\mathrm{Parp}^{-/-}$resulted in reduced $\mathrm{CD} 4^{+} \mathrm{CD} 8^{+}$thymocyte cellularity, the overexpression of the proapoptotic proteins Noxa and Puma as well as a reduced expression of the T-cell receptor (TCR) $\alpha$ [21,71-74]. The importance of the PAR metabolizing enzymes PARP1 and PARP2 is further illustrated by the fact that a double k.o. results in embryonic death. This can be observed already in the early stage of gastrulation leading to a complete loss of the offspring [70,75].

After the first demonstration of PARP1 and PARP2 functions using k.o. mice, another breakthrough was made by the disruption of the PAR degrading enzyme PARG. First, Koh and colleagues targeted exon 4 within the parg gene [76]. This led to early peri-implantation lethality resulting in the failure of the embryos to progress and the subsequent degeneration of the blastocyst. However, embryonic trophoblast stem cell lines established from early PARG null embryos could be kept viable in culture, but only when co-cultured with the traditional PARP inhibitor benzamide $(0.5 \mathrm{mM})$. Moreover, the 
$\mathrm{Parg}^{-/-}$cells were characterized by reduced growth, an accumulation of PAR and an increased sensitivity to the alkylating agent $N$-methyl- $N$ '-nitro- $N$-nitrosoguanidine (MNNG, 20 and $100 \mu \mathrm{M}$ ). An improved strategy to impair Parg gene in mice to overcome lethality problems was reported by Cortes et al. [77]. They targeted exons 2 and 3 resulting in the depletion of only $\mathrm{PARG}_{110}$ protein isoform normally found in the cell nucleus. Due to this elegant approach the mice were viable, fertile and phenotypically normal but hypersensitive to alkylating agents (MNU, $150 \mathrm{mg} / \mathrm{kg}$ of body weight) and ionizing radiation (10 Gy of whole body $\gamma$-radiation). However, Meyer-Ficca et al. reported a reduced number of litters as well as a decreased number of pups per litter in Parg $^{42-3}$ mice [78]. Moreover, the $\mathrm{Parg}^{42-3}$ mice were prone to septic shock induced by lipopolysaccharides (LPS, 30 $\mathrm{mg} / \mathrm{kg}$ of body weight). Both PARG manipulated mouse models are presented in Table 1.

\subsection{RNA Interference}

Sense RNAs have been typically introduced as negative specificity controls using RNAs synthesized in vitro in antisense studies in the 1990s [79]. Interestingly, Guo and Kemphues found that control sense as well as antisense RNA molecules resulted in similar phenocopies when administered to the worm Caenorhabditis elegans [80]. Further studies in C. elegans revealed that the interfering RNA could be transported from the site of initial delivery to most cells and tissues in the worm and this systemic response was termed RNA interference or RNAi [81]. Subsequently, it was discovered that double-stranded RNA (dsRNA) rather than single-stranded antisense RNA (ssRNA) was responsible for the sequence specific degradation of targeted endogenous mRNA in C. elegans [82]. This form of posttranscriptional gene silencing in response to transgene sequences was previously demonstrated in plants and also in fungi representing an evolutionary well-conserved mechanism. Napoli et al. introduced a transgene designed to overexpress chalcone synthase putatively leading to an increase in purple pigment production in petunia flowers. Surprisingly, more than $40 \%$ of the transgenic plants developed white or variegated flowers rather than purple [83]. A similar phenomenon of target gene repression in a different model organism was discovered in experiments using the fungus Neurosporus crassa [84].

Table 1. Murine phenotypes of genetic PARP or PARG disruption.

\begin{tabular}{cccc}
\hline Deletion & Phenotype & Ref. \\
\hline Parp1 & Accumulation of DNA strand breaks and impaired DNA repair & {$[66-68]$} \\
& High genomic instability & \\
& Hypersensitivity to $\gamma$-irradiation and alkylating agents & \\
Parp2 & No defects in viability, fertility, development or tissue differentiation \\
& High genomic instability & {$[70,73]$} \\
& - & Hypersensitivity to $\gamma$-irradiation and alkylating agents & \\
Parp1, Parp2 & - & No defects in viability, fertility, development or tissue differentiation \\
Parg & Embryonic lethality at onset of gastrulation & {$[70,75]$} \\
Parg & - & Peri-implantation lethality & {$[76]$} \\
& - & Increased responses to genotoxic treatment and septic shock & {$[77,78]$} \\
\hline
\end{tabular}


A first mechanistic model resolving this phenomenon originated from comprehensive biochemical and genetic studies on flies, worms, fungi, plants, and mammalian cells (Figure 4, reviewed by Hutvagner et al. [85]). The RNA-silencing response starts by processing the trigger dsRNA molecules into smaller fragments with 21 to $25 \mathrm{bp}$ in size that are characterized by 3' dinucleotide overhangs. The activity of an enzyme called Dicer is required for this process and it depends on adenosine triphosphate (ATP). This multidomain protein contains an ATP-dependent RNA helicase, a Piwi Argonaut and Zwille (PAZ) domain, two tandem RNase III domains, and a dsRNA-binding domain [86]. The final products of the Dicer activity were termed short interfering RNAs (siRNAi) [87]. Each siRNA binds subsequently to the RNA-induced silencing complex (RISC) that is composed of different protein subunits. In a next step, the siRNAs become unwound due to a helicase component of RISC. This allows base pairing between the antisense strand and the target mRNA [88]. Endonucleolytic cleavage of the target mRNA via the endonuclease Ago2 leads to fragments missing polyA tail or missing 5' 7-Methylguanosine cap leading subsequently to degradation [79]. The mechanistic overview is shown in Figure 4.

To date, four different types of small RNA molecules are described to possess RNA interference.

(I) Short interfering RNA (siRNA)

Synthetic siRNA was the first RNAi technology used in mammalian cells for sequence specific gene silencing [89]. The siRNA directly incorporates into RISC, where its guide strands binds and cleaves the target mRNA. After the release of cleaved mRNA, the guide-strand-bound RISC binds to another mRNA starting a new cleavage cycle. siRNAs are capable to cleave and subsequently suppress cytoplasmic or nuclear target mRNA [90].

(II) Short hairpin RNA (shRNA)

Short hairpin RNA (shRNA) has been developed as an alternative strategy to siRNA and was aimed for long-term gene silencing [91,92]. The shRNA is transcribed in the nucleus out of an expression vector bearing a short dsDNA sequence with a hairpin loop. The resulting transcript becomes further processed after coupling to the cytoplasmic RISC, following the identical fate as described above for siRNA. In practice, several aspects of shRNA differ intrinsically from siRNA reviewed by Rao et al. [93].

(III) MicroRNA (miRNA)

MicroRNAs (miRNAs) are highly conserved small noncoding RNAs, which play a role in regulating physiological and pathological cell functions. They are initially transcribed in the nucleus as primary transcripts from precursors generally located within either intergenic regions or introns of protein coding sequences [94]. After processing by an RNAse III endonuclease, the pre-miRNAs are exported to the cytoplasm and further cleaved by the Dicer producing 20-23 bp mature miRNAs. The miRNAs are subsequently loaded into RISC eliciting transcriptional inhibition with target mRNA degradation or sequestration in cytoplasmic P-bodies [95]. Compared to siRNAs and shRNAs, which require a perfect match with the target mRNA, miRNAs exert typically translational inhibition by binding to a partially complementary mRNA (Figure 4). Therefore, the change in the expression of a single miRNA may affect hundreds of different genes [96,97]. 


\section{(IV) Bi-functional shRNA (bi-shRNA)}

Bi-functional shRNAs (bi-shRNAs) were developed to exploit both the cleavage and translational inhibitions mechanisms of RNAi [93]. They consist of two stem-loop shRNAs structures. The cleavage-dependent unit perfectly matches passenger and guide-strand, whereas the cleavage-independent unit is composed of a mismatched double-strand. Both units are embedded in a miR-30 scaffold encoded in a plasmid vector. The mature transcript of the cleavage-dependent part is loaded into RISC in complex with the endonuclease Ago2. The processed transcript of the cleavage-independent unit functions as a miRNA by binding to RISC inducing mRNA degradation/P-body sequestration or transcriptional inhibition. In general, the mechanism of bishRNAs leads to higher efficacy and greater durability compared with siRNA and miRNA [98].

The current understanding of therapeutic implementation of all these different small RNA approaches has been extensively reviewed: Seyhan discussed the progress and arising challenges in developing RNAi therapeutics against genetic diseases [99]. The current status of RNAi-based anticancer therapy and their potential clinical application is discussed by Wang et al. [98] and Bora et al. [100].

\subsection{The Use of RNA Interference against PARP Enzymes}

The possibility to suppress the expression of a specific protein in cell cultures has attracted a lot of interest. Moreover, the PAR research was extended to cell systems other than that of murine origin, due to RNAi techniques. Historically the first experiments using RNAi as a tool targeting PAR metabolism were performed aiming the knock down (k.d.) of PARP1 (Table 2).

Already in 2002, Gan et al. reported the silencing of PARP1 protein caused by the transfection of PARP1-specific dsRNA molecules in murine neuroblastoma cells [101]. They targeted the N- as well as the C-terminus of the Parpl gene, and both approaches diminished the expression of the corresponding protein. Further, this study confirmed the resistance of PARP1 abrogated cells to oxygen-glucose deprivation as a functional consequence. This phenotype was previously demonstrated in cells lacking PARP1 due to genetic ablation. Therefore they suggested the application of RNAi as a powerful tool to study gene functions in cells. In 2004, Kameoka et al. introduced RNAi against PARP1 in human cell cultures. In this report, the authors studied the HIV-1 replication within HeLa and J111 cells that have an impaired PARP1 expression [102]. One of the obvious advantages to prefer RNAi rather than chemicals for enzyme inhibition purposes is its specificity. This was demonstrated in an elegant study by Shah et al. in 2005 [103]. They developed and compared RNAi approaches targeting the C-terminus of the parpl gene in human, murine and hamster cells and investigated the impact of PARP1 k.d. on the expression level of PARP2. As discussed above PARP2 exhibits a significant amino acid and nucleotide sequence similarity with PARP1 in the C-terminal domain. The RNAi target sequences for PARP1 determined in this study have only three (for the murine) or greater than five (hamster, human) mismatches with the parp2 gene. Shah et al. found no impact on PARP2 expression in the tested PARP1 k.d. models as tested by Western blot analyses. They concluded that RNAi against PARP1 does not interfere with its most related protein PARP2 and since other PARP-homologs have even greater disparity to PARP2, it is not likely to affect them by RNAi against PARP1 [103]. To date, RNAi against PARP1 has been applied to at least 20 different human cell types 
and to cells derived from other mammalian species (Table 2). These include immortalized, primary and cultures from embryonic stem cells.

Figure 4. The pathway of RNA interference. (a) Highly specific siRNA which are 21-23 nt double-stranded RNA (dsRNA) duplexes in size with symmetric 2-3 nucleotide 3' overhangs and 5' phosphate $(\mathrm{P})$ and 3' hydroxyl $(\mathrm{OH})$ groups. (b) The dsRNA is cleaved by Dicer in an ATP-dependent reaction. The siRNAs are subsequently incorporated into a multicomponent RNA-inducing silencing complex (RISC). Activated RISC unwinds the siRNA in an ATP-dependent fashion. The resulting antisense strand guides the RISC to its complementary mRNA before endonucleolytic cleavage of target mRNA. The free ends of the mRNA fragments are rapidly degraded by cytoplasmic nucleases. This ultimately results in the loss of protein expression. (c) Dicer cleaves the miRNA precursor to produce $22 \mathrm{nt}$ miRNA. The single-stranded miRNAs are incorporated into RISC, followed by target recognition and final translational inhibition [104].

(a)

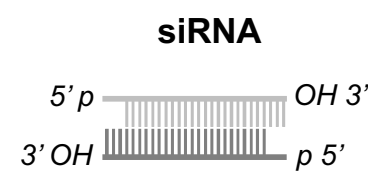

(c)
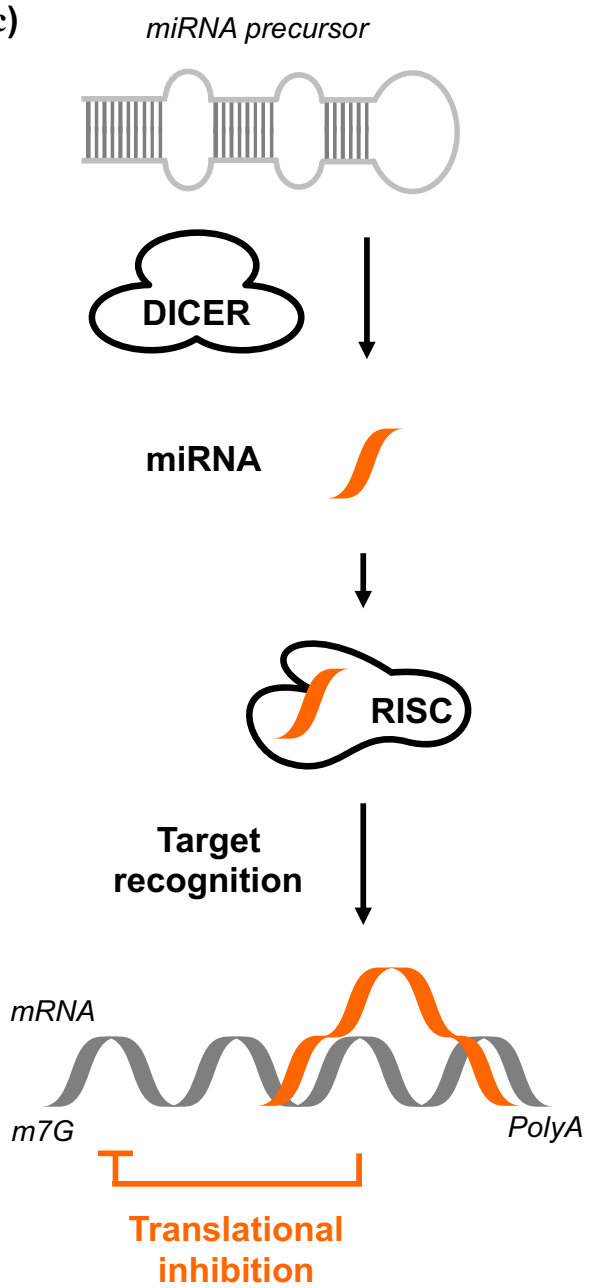

(b)

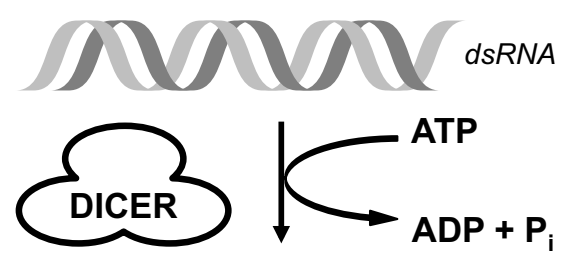

SiRNA
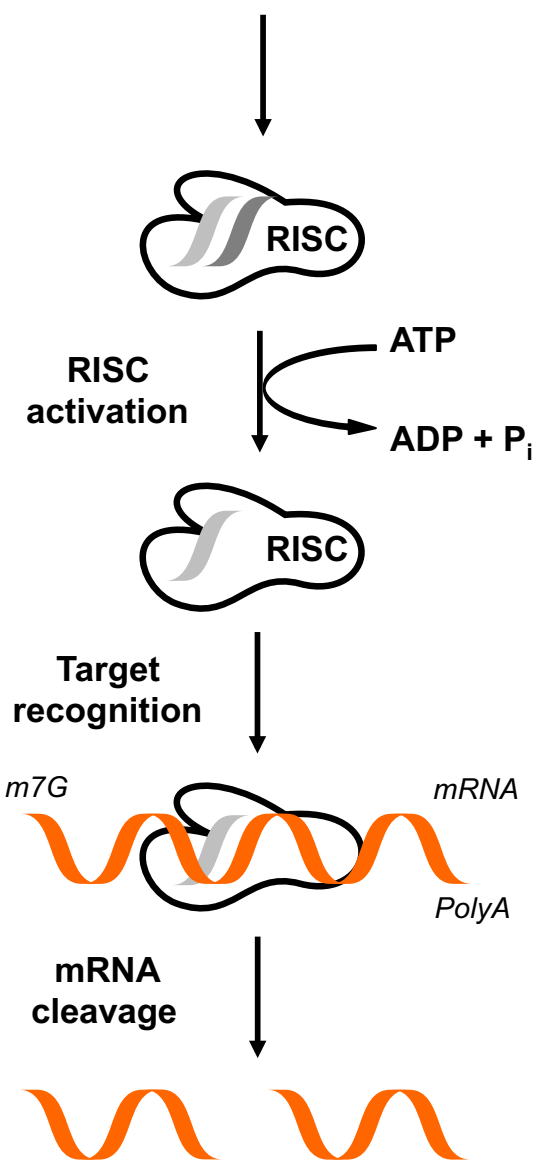

Degraded mRNA 
Table 2. RNAi against PARP1 in mammalian cells. Studies labeled with * provide detailed targeting sequence information.

\begin{tabular}{|c|c|c|c|}
\hline Cell line & Cell type & Species & References \\
\hline 293 & Embryonic kidney cells & Human & {$[105]^{*},[106,107]$} \\
\hline 3T3-L1 & Preadipocytes & Mouse & {$[108]^{*}$} \\
\hline A20 & B-cell lymphoma & Mouse & [109] \\
\hline A549 & Lung adenocarcinoma epithelial & Human & {$[110,111]^{*},[107,112-114]$} \\
\hline AGYNB010 & Neuroblastoma & Mouse & {$[101]^{*}$} \\
\hline bEnd.3 & Cerebral vascular endothelial & Mouse & {$[114]$} \\
\hline $\mathrm{CHO}$ & Ovarian cells & Chinese hamster & {$[103]^{*}$} \\
\hline EW7 & Ewing sarcoma & Human & {$[115]^{*}$} \\
\hline GM00637 & SV-40 transformed skin fibroblasts & Human & {$[116]^{*}$} \\
\hline H9 hESCs & Embryonic stem cells & Human & {$[117]^{*}$} \\
\hline $\mathrm{HaCaT}$ & Keratinocytes & Human & {$[118,119]$} \\
\hline НCТ-116 & Colon adenocarcinoma & Human & {$[120,121]$} \\
\hline $\mathrm{HeLa}$ & Cervix carcinoma & Human & {$[102,122-128]^{*},[129,130]$} \\
\hline HepG2 & Hepatocytes & Human & {$[131]$} \\
\hline HUVEC & Endothelial cells & Human & [132] \\
\hline $\mathrm{J} 111$ & Acute monocytic leukemia & Human & {$[102]^{*}$} \\
\hline Jurkat & T-cell lymphoma (Type II) & Human & {$[133]^{*}$} \\
\hline MCF-7 & Breast cancer & Human & {$[134]^{*}$} \\
\hline MEF & Fibroblasts & Mouse & {$[25,103,135,136]^{*}$} \\
\hline NB4 & Acute promyelocytic leukemia & Human & {$[115]^{*}$} \\
\hline NIT-1 & Insulinoma cells & Mouse & {$[137]^{*}$} \\
\hline $\mathrm{PC} 12$ & Prostate cancer & Human & {$[138]$} \\
\hline Primary & Fibroblasts & Human & {$[139]^{*}$} \\
\hline Primary & Cerebral cortex neurons & Rat & {$[140]$} \\
\hline Primary & Rheumatoid arthritis synovial cells & Human & {$[141,142]$} \\
\hline Primary & Vascular smooth muscle & Rat & [143] \\
\hline Ramos & Burkitt's lymphoma & Human & [109] \\
\hline SHSY5Y & Neuroblastoma & Human & [144] \\
\hline SW480 & Colorectal adenocarcinoma & Human & {$[145]$} \\
\hline WRL-68 & Liver cells & Human & [146] \\
\hline
\end{tabular}

RNAi molecules targeting PARP2 were next developed to study distinct and overlapping functions of PARP1 and PARP2 in a variety of mammalian cells (Table 3). As described above, PARP2 k.o. has created lethality in conjunction with PARP1 k.o. in mice [70]. Here the application of RNAi techniques helped to overcome this problem. Within the last years we have investigated the combination of either double RNAi (PARP1 and PARP2) in human cells [122,127] or the combination of genetic ablation of parp1 gene together with RNAi against PARP2 in murine cell cultures [135]. None of the tested systems revealed a lethal phenotype and the cells kept the ability to attach and proliferate under normal culture conditions. Woodhouse et al. silenced PARP1 and PARP2 alone or in combination in cell cultures derived from primary human fibroblasts and no toxicity was reported due to double silencing [139]. This putative discrepancy compared to the Parp $^{-/-}$Parp $^{-/-}$ mouse models is most likely related to the noncomplete gene disruption mediated by RNAi in all 
studies [122,135,139,145]. However, here the implication of RNAi provides advantages to study distinct functions of closely related proteins and overcomes lethality problems and the lack of specific inhibitors. Whereas PARP1 and PARP2 are the most studied members of the PARP enzyme family, RNAi was used as a tool to suppress other PARP enzymes including PARP3 [126,147,148], PARP4 (vault-PARP) [126], PARP5A (Tankyrase 1) [126,149], PARP5B (Tankyrase 2) [126], PARP7 (TIPARP) [150] and PARP16 [151].

Table 3. RNAi against PARP2 in mammalian cells. Studies labeled with * provide detailed targeting sequence information.

\begin{tabular}{cccc}
\hline Cell line & Cell type & Species & References \\
\hline 293 & Embryonic kidney cells & Human & {$[72]^{*},[152]$} \\
A549 & Lung adenocarcinoma epithelial & Human & {$[111]$} \\
BHK & Baby hamster kidney fibroblast & Chinese hamster & {$[152]$} \\
C2C12 & Myoblasts & Mouse & {$[153]^{*}$} \\
HeLa & Cervix carcinoma & Human & {$[122,126,127]^{*}$} \\
MEF & Fibroblasts & Mouse & {$[135]^{*}$} \\
MOVAS & Aortic smooth muscle & Mouse & {$[154]^{*}$} \\
SW480 & Colorectal adenocarcinoma & Human & {$[145]$} \\
\hline
\end{tabular}

Moreover, RNAi approaches aiming at the organismic level of invertebrates, mice and plants have been performed to clarify PAR metabolism in vivo and/or to investigate a possible clinical application of RNAi itself. Gravel et al. published in 2004 RNAi experiments targeting the human tankyrase related gene pme-5 in the invertebrate $C$. elegans [155]. The same group demonstrated later the effective application of RNAi against the C. elegans PARGs pme-3 and pme-4 [156]. The group of Tulin studied PAR metabolism in flies (Drosophila melanogaster). They established and investigated RNAi approaches against PARP1 and its counterpart PARG and clarified their involvement in gene expression [157,158].

Popoff et al. investigated antisense oligonucleotides targeting PARP2 in a colitis mouse model [159]. Recently, Goldberg and co-workers established whole body silencing of PARP1 studying nanoparticle-mediated siRNA delivery in mice [160]. In this analysis, they investigated the tumor dissemination in a Brca1-deficient genetic background after application of siRNAs targeting PARP1. The stress tolerance of PARP1 and PARP2 impaired Arabidopsis thaliana as well as oilseed rape (Brassica napus) plants have been determined using RNAi tools [161,162].

\subsection{The Use of RNA Interference against PARG}

The lack of specific chemical inhibitors and the drastic lethal phenotype of $\mathrm{Parg}^{-/-}$cells as discussed above evolved into a set of studies using RNAi to suppress PARG in cells (Table 4). We reported previously that silencing of the parg gene in murine and human cells lead to an accumulation of PAR after oxidative and alkylating DNA insults [122,163]. The delayed degradation of PAR molecules had a protective effect in particular when cells were challenged with the oxidant hydrogen peroxide $\left(\mathrm{H}_{2} \mathrm{O}_{2}\right)$. Recently, Feng et al. confirmed this finding in human breast cancer cells treated with alkylating agents [164]. Interestingly, the investigation of PARG silencing in mammalian cells after 
genotoxic challenge has resulted in a hypersensitivity phenotype, as well $[111,165,166]$. In these studies, cells treated with siRNA targeting PARG forced cell death due to PAR accumulation, similar to results obtained in cells with a genetic PARG impairment [76]. Andrabi et al. showed that artificially introduced PAR molecules trigger an apoptosis inducing factor (AIF) mediated cell death pathway [165]. By contrast, an increase of cytoplasmic $\mathrm{Ca}^{2+}$ independent from PARP activity has been implicated in the release of AIF from mitochondria subsequently leading to cell death [167]. We followed this hypothesis and found that the inhibition of PARG using RNAi diminishes the occurrence of free ADPR molecules that can trigger a rise in cytosolic $\mathrm{Ca}^{2+}$ via the transient receptor potential mediated channels 2 (TRPM2) [25]. As a consequence, AIF translocation-indicative of cell deathwas abrogated. To date, this $\mathrm{Ca}^{2+}$ channel is the only one activated by monomeric ADPR, and it is dependent on PARP/PARG activity [25,168-171]. This finding resolves a long lasting controversy about the roles of PAR and ADPR as cell death signals.

Table 4. RNAi against PARG in mammalian cells. Studies labeled with * provide detailed targeting sequence information.

\begin{tabular}{cccc}
\hline Cell line & Cell type & Species & References \\
\hline 16 HBE & Bronchial epithelial & Human & {$[172]^{*}$} \\
293 & Embryonic kidney cells & Human & {$[107]$} \\
A549 & Lung adenocarcinoma epithelial & Human & {$[111]^{*},[107]$} \\
HeLa & Cervix carcinoma & Human & {$[122,163,165,166,173]^{*}$} \\
LoVo & Colon carcinoma & Human & {$[174,175]^{*}$} \\
MCF-7 & Breast cancer & Human & {$[134,163,164]^{*},[176]$} \\
MEF & Fibroblasts & Mouse & {$[25,38,163]^{*}$} \\
Primary & Rheumatoid arthritis synovial cells & Human & {$[142]^{*}$} \\
Primary & Glioblastoma & Human & {$[177]^{*}$} \\
RAW 264.7 & Macrophages & Mouse & {$[178]^{*}$} \\
\hline
\end{tabular}

\section{Conclusions}

The implementation of RNAi has markedly expanded our knowledge of the PAR metabolizing system. It has helped to demonstrate distinct functions attributable to PARP members and PARG in a nonmurine background. Moreover RNAi helped overcome lethality problems in mice that were discovered when PARP1 and PARP2 were ablated simultaneously or when the parg gene was depleted. The targeting specificity of the RNAi approach is considerably better than chemical inhibitors, which often do not distinguish between individual PARP members or fail to inhibit at all in a cellular context because of bioavailability problems (PARG).

\section{Acknowledgments}

This work was supported by the Swiss National Science Foundation, and a grant from the Lotte and Adolf Hotz-Sprenger foundation, Zurich awarded to F.R.A. 


\section{References and Notes}

1. Ame, J.C.; Spenlehauer, C.; de Murcia, G. The parp superfamily. Bioessays 2004, 26, 882-893.

2. Schreiber, V.; Dantzer, F.; Ame, J.C.; de Murcia, G. Poly(adp-ribose): Novel functions for an old molecule. Nat. Rev. Mol. Cell. Biol. 2006, 7, 517-528.

3. Heeres, J.T.; Hergenrother, P.J. Poly(adp-ribose) makes a date with death. Current Opin. Chem. Biol. 2007, 11, 644-653.

4. Hottiger, M.O.; Hassa, P.O.; Luscher, B.; Schuler, H.; Koch-Nolte, F. Toward a unified nomenclature for mammalian adp-ribosyltransferases. Trends Biochem. Sci. 2010, 35, 208-219.

5. Gibson, B.A.; Kraus, W.L. New insights into the molecular and cellular functions of poly(adp-ribose) and parps. Nat. Rev. Mol. Cell Biol. 2012, 13, 411-424.

6. Langelier, M.F.; Servent, K.M.; Rogers, E.E.; Pascal, J.M. A third zinc-binding domain of human poly(adp-ribose) polymerase-1 coordinates DNA-dependent enzyme activation. J. Biol. Chem. 2008, 283, 4105-4114.

7. Tao, Z.; Gao, P.; Hoffman, D.W.; Liu, H.W. Domain c of human poly(adp-ribose) polymerase-1 is important for enzyme activity and contains a novel zinc-ribbon motif. Biochemistry 2008, 47, 5804-5813.

8. Hassa, P.O.; Haenni, S.S.; Elser, M.; Hottiger, M.O. Nuclear adp-ribosylation reactions in mammalian cells: Where are we today and where are we going? Microbiol. Mol. Biol. Rev. MMBR 2006, 70, 789-829.

9. Sallmann, F.R.; Vodenicharov, M.D.; Wang, Z.Q.; Poirier, G.G. Characterization of sparp-1. An alternative product of parp-1 gene with poly(adp-ribose) polymerase activity independent of DNA strand breaks. J. Biol. Chem 2000, 275, 15504-15511.

10. Gagne, J.P.; Isabelle, M.; Lo, K.S.; Bourassa, S.; Hendzel, M.J.; Dawson, V.L.; Dawson, T.M.; Poirier, G.G. Proteome-wide identification of poly(adp-ribose) binding proteins and poly(adpribose)-associated protein complexes. Nucleic Acids Res. 2008, 36, 6959-6976.

11. Timinszky, G.; Till, S.; Hassa, P.O.; Hothorn, M.; Kustatscher, G.; Nijmeijer, B.; Colombelli, J.; Altmeyer, M.; Stelzer, E.H.; Scheffzek, K.; et al. A macrodomain-containing histone rearranges chromatin upon sensing parp1 activation. Nat. Struct. Mol. Biol. 2009, 16, 923-929.

12. Gottschalk, A.J.; Timinszky, G.; Kong, S.E.; Jin, J.; Cai, Y.; Swanson, S.K.; Washburn, M.P.; Florens, L.; Ladurner, A.G.; Conaway, J.W.; et al. Poly(adp-ribosyl)ation directs recruitment and activation of an atp-dependent chromatin remodeler. Proc. Natl. Acad. Sci. USA 2009, 106, 13770-13774.

13. Ahel, D.; Horejsi, Z.; Wiechens, N.; Polo, S.E.; Garcia-Wilson, E.; Ahel, I.; Flynn, H.; Skehel, M.; West, S.C.; Jackson, S.P.; et al. Poly(adp-ribose)-dependent regulation of DNA repair by the chromatin remodeling enzyme alc1. Science 2009, 325, 1240-1243.

14. Realini, C.A.; Althaus, F.R. Histone shuttling by poly(adp-ribosylation). J. Biol. Chem. 1992, 267, 18858-18865.

15. Malanga, M.; Pleschke, J.M.; Kleczkowska, H.E.; Althaus, F.R. Poly(adp-ribose) binds to specific domains of p53 and alters its DNA binding functions. J. Biol. Chem. 1998, 273, 11839-11843. 
16. Pleschke, J.M.; Kleczkowska, H.E.; Strohm, M.; Althaus, F.R. Poly(adp-ribose) binds to specific domains in DNA damage checkpoint proteins. J. Biol. Chem. 2000, 275, 40974-40980.

17. Ogata, N.; Ueda, K.; Kagamiyama, H.; Hayaishi, O. Adp-ribosylation of histone hl. Identification of glutamic acid residues 2, 14, and the cooh-terminal lysine residue as modification sites. J. Biol. Chem. 1980, 255, 7616-7620.

18. Tulin, A.; Spradling, A. Chromatin loosening by poly(adp)-ribose polymerase (parp) at drosophila puff loci. Science 2003, 299, 560-562.

19. Beneke, S. Regulation of chromatin structure by poly(adp-ribosyl)ation. Front. Genet. 2012, 3, 169.

20. Ame, J.C.; Rolli, V.; Schreiber, V.; Niedergang, C.; Apiou, F.; Decker, P.; Muller, S.; Hoger, T.; Menissier-de Murcia, J.; de Murcia, G. Parp-2, a novel mammalian DNA damage-dependent poly(adp-ribose) polymerase. J. Biol. Chem. 1999, 274, 17860-17868.

21. Yelamos, J.; Schreiber, V.; Dantzer, F. Toward specific functions of poly(adp-ribose) polymerase-2. Trends Mol. Med. 2008, 14, 169-178.

22. Pion, E.; Ullmann, G.M.; Ame, J.C.; Gerard, D.; de Murcia, G.; Bombarda, E. DNA-induced dimerization of poly(adp-ribose) polymerase-1 triggers its activation. Biochemistry 2005, 44, 14670-14681.

23. Schreiber, V. Parp-2, structure-function relationship. In Poly(adp-ribosyl)ation; Burkle, A., Ed.; Landes Bioscience: Austin, TX, USA, 2004; pp. 13-31.

24. Schreiber, V.; Ame, J.C.; Dolle, P.; Schultz, I.; Rinaldi, B.; Fraulob, V.; Menissier-de Murcia, J.; de Murcia, G. Poly(adp-ribose) polymerase-2 (parp-2) is required for efficient base excision DNA repair in association with parp-1 and xrcc1. J. Biol. Chem. 2002, 277, 23028-23036.

25. Blenn, C.; Wyrsch, P.; Bader, J.; Bollhalder, M.; Althaus, F.R. Poly(adp-ribose)glycohydrolase is an upstream regulator of ca2+ fluxes in oxidative cell death. Cell. Mol. Life Sci. CMLS 2011, 68, 1455-1466.

26. Wielckens, K.; Bredehorst, R.; Adamietz, P.; Hilz, H. Mono adp-ribosylation and poly adpribosylation of proteins in normal and malignant tissues. Adv. Enzyme Regul. 1982, 20, $23-37$.

27. Wielckens, K.; Schmidt, A.; George, E.; Bredehorst, R.; Hilz, H. DNA fragmentation and nad depletion. Their relation to the turnover of endogenous mono(adp-ribosyl) and poly(adp-ribosyl) proteins. J. Biol. Chem. 1982, 257, 12872-12877.

28. Alvarez-Gonzalez, R.; Althaus, F.R. Poly(adp-ribose) catabolism in mammalian cells exposed to DNA-damaging agents. Mutat. Res. 1989, 218, 67-74.

29. Brochu, G.; Shah, G.M.; Poirier, G.G. Purification of poly(adp-ribose) glycohydrolase and detection of its isoforms by a zymogram following one- or two-dimensional electrophoresis. Anal. Biochem. 1994, 218, 265-272.

30. Davidovic, L.; Vodenicharov, M.; Affar, E.B.; Poirier, G.G. Importance of poly(adp-ribose) glycohydrolase in the control of poly(adp-ribose) metabolism. Exp. Cell. Res. 2001, 268, 7-13.

31. Braun, S.A.; Panzeter, P.L.; Collinge, M.A.; Althaus, F.R. Endoglycosidic cleavage of branched polymers by poly(adp-ribose) glycohydrolase. Eur. J. Biochem. 1994, 220, 369-375.

32. Alvarez-Gonzalez, R.; Jacobson, M.K. Characterization of polymers of adenosine diphosphate ribose generated in vitro and in vivo. Biochemistry 1987, 26, 3218-3224. 
33. Ame, J.C.; Apiou, F.; Jacobson, E.L.; Jacobson, M.K. Assignment of the poly(adp-ribose) glycohydrolase gene (parg) to human chromosome 10q11.23 and mouse chromosome 14b by in situ hybridization. Cytogenet Cell. Genet. 1999, 85, 269-270.

34. Hatakeyama, K.; Nemoto, Y.; Ueda, K.; Hayaishi, O. Purification and characterization of poly(adp-ribose) glycohydrolase. Different modes of action on large and small poly(adp-ribose). J. Biol. Chem. 1986, 261, 14902-14911.

35. Meyer, R.G.; Meyer-Ficca, M.L.; Whatcott, C.J.; Jacobson, E.L.; Jacobson, M.K. Two small enzyme isoforms mediate mammalian mitochondrial poly(adp-ribose) glycohydrolase (parg) activity. Exp. Cell. Res. 2007, 313, 2920-2936.

36. Oka, S.; Kato, J.; Moss, J. Identification and characterization of a mammalian 39-kda poly(adpribose) glycohydrolase. J. Biol. Chem. 2006, 281, 705-713.

37. Niere, M.; Kernstock, S.; Koch-Nolte, F.; Ziegler, M. Functional localization of two poly(adpribose)-degrading enzymes to the mitochondrial matrix. Mol. Cell. Biol. 2008, 28, 814-824.

38. Niere, M.; Mashimo, M.; Agledal, L.; Dolle, C.; Kasamatsu, A.; Kato, J.; Moss, J.; Ziegler, M. Adp-ribosylhydrolase 3 (arh3), not poly(adp-ribose) glycohydrolase (parg) isoforms, is responsible for degradation of mitochondrial matrix-associated poly(adp-ribose). J. Biol. Chem. 2012, 287, 16088-16102.

39. Menear, K.A.; Adcock, C.; Boulter, R.; Cockcroft, X.L.; Copsey, L.; Cranston, A.; Dillon, K.J.; Drzewiecki, J.; Garman, S.; Gomez, S.; et al. 4-[3-(4-cyclopropanecarbonylpiperazine-1carbonyl)-4-fluorobenzyl]-2h-phthalazin- 1-one: A novel bioavailable inhibitor of poly(adpribose) polymerase-1. J. Med. Chem. 2008, 51, 6581-6591.

40. Penning, T.D.; Zhu, G.D.; Gandhi, V.B.; Gong, J.; Liu, X.; Shi, Y.; Klinghofer, V.; Johnson, E.F.; Donawho, C.K.; Frost, D.J.; et al. Discovery of the poly(adp-ribose) polymerase (parp) inhibitor 2-[(r)-2-methylpyrrolidin-2-yl]-1h-benzimidazole-4-carboxamide (abt-888) for the treatment of cancer. J. Med. Chem. 2009, 52, 514-523.

41. Park, S.R.; Chen, A. Poly(adenosine diphosphate-ribose) polymerase inhibitors in cancer treatment. Hematol. Oncol. Clin. North. Am. 2012, 26, 649-670, ix.

42. Mangerich, A.; Burkle, A. How to kill tumor cells with inhibitors of poly(adp-ribosyl)ation. Int. J. Cancer 2011, 128, 251-265.

43. Rankin, P.W.; Jacobson, E.L.; Benjamin, R.C.; Moss, J.; Jacobson, M.K. Quantitative studies of inhibitors of adp-ribosylation in vitro and in vivo. J. Biol. Chem. 1989, 264, 4312-4317.

44. Monti, D.; Cossarizza, A.; Salvioli, S.; Franceschi, C.; Rainaldi, G.; Straface, E.; Rivabene, R.; Malorni, W. Cell death protection by 3-aminobenzamide and other poly(adp-ribose)polymerase inhibitors: Different effects on human natural killer and lymphokine activated killer cell activities. Biochem. Biophys. Res. Commun. 1994, 199, 525-530.

45. Heller, B.; Wang, Z.Q.; Wagner, E.F.; Radons, J.; Burkle, A.; Fehsel, K.; Burkart, V.; Kolb, H. Inactivation of the poly(adp-ribose) polymerase gene affects oxygen radical and nitric oxide toxicity in islet cells. J. Biol. Chem. 1995, 270, 11176-11180.

46. Nakajima, H.; Kakui, N.; Ohkuma, K.; Ishikawa, M.; Hasegawa, T. A newly synthesized poly(adp-ribose) polymerase inhibitor, dr2313 [2-methyl-3,5,7,8-tetrahydrothiopyrano[4,3-d]pyrimidine-4-one]: Pharmacological profiles, neuroprotective effects, and therapeutic time window in cerebral ischemia in rats. J. Pharmacol. Exp. Ther. 2005, 312, 472-481. 
47. Abdelkarim, G.E.; Gertz, K.; Harms, C.; Katchanov, J.; Dirnag1, U.; Szabo, C.; Endres, M. Protective effects of pj34, a novel, potent inhibitor of poly(adp-ribose) polymerase (parp) in in vitro and in vivo models of stroke. Int. J. Mol. Med. 2001, 7, 255-260.

48. Mabley, J.G.; Jagtap, P.; Perretti, M.; Getting, S.J.; Salzman, A.L.; Virag, L.; Szabo, E.; Soriano, F.G.; Liaudet, L.; Abdelkarim, G.E.; et al. Anti-inflammatory effects of a novel, potent inhibitor of poly (adp-ribose) polymerase. Inflamm. Res. 2001, 50, 561-569.

49. Garcia Soriano, F.; Virag, L.; Jagtap, P.; Szabo, E.; Mabley, J.G.; Liaudet, L.; Marton, A.; Hoyt, D.G.; Murthy, K.G.; Salzman, A.L.; et al. Diabetic endothelial dysfunction: The role of poly(adp-ribose) polymerase activation. Nat. Med. 2001, 7, 108-113.

50. Faro, R.; Toyoda, Y.; McCully, J.D.; Jagtap, P.; Szabo, E.; Virag, L.; Bianchi, C.; Levitsky, S.; Szabo, C.; Sellke, F.W. Myocardial protection by pj34, a novel potent poly (adp-ribose) synthetase inhibitor. Ann. Thorac. Surg. 2002, 73, 575-581.

51. Boulton, S.; Pemberton, L.C.; Porteous, J.K.; Curtin, N.J.; Griffin, R.J.; Golding, B.T.; Durkacz, B.W. Potentiation of temozolomide-induced cytotoxicity: A comparative study of the Biological effects of poly(adp-ribose) polymerase inhibitors. Br. J. Cancer 1995, 72, 849-856.

52. Griffin, R.J.; Srinivasan, S.; Bowman, K.; Calvert, A.H.; Curtin, N.J.; Newell, D.R.; Pemberton, L.C.; Golding, B.T. Resistance-modifying agents. 5. Synthesis and Biol.ogical properties of quinazolinone inhibitors of the DNA repair enzyme poly(adp-ribose) polymerase (parp). J. Med. Chem. 1998, 41, 5247-5256.

53. Delaney, C.A.; Wang, L.Z.; Kyle, S.; White, A.W.; Calvert, A.H.; Curtin, N.J.; Durkacz, B.W.; Hostomsky, Z.; Newell, D.R. Potentiation of temozolomide and topotecan growth inhibition and cytotoxicity by novel poly(adenosine diphosphoribose) polymerase inhibitors in a panel of human tumor cell lines. Clin. Cancer Res. 2000, 6, 2860-2867.

54. Suto, M.J.; Turner, W.R.; Arundel-Suto, C.M.; Werbel, L.M.; Sebolt-Leopold, J.S. Dihydroisoquinolinones: The design and synthesis of a new series of potent inhibitors of poly(adp-ribose) polymerase. Anticancer Drug Des. 1991, 6, 107-117.

55. Moroni, F.; Meli, E.; Peruginelli, F.; Chiarugi, A.; Cozzi, A.; Picca, R.; Romagnoli, P.; Pellicciari, R.; Pellegrini-Giampietro, D.E. Poly(adp-ribose) polymerase inhibitors attenuate necrotic but not apoptotic neuronal death in experimental models of cerebral ischemia. Cell Death Differ. 2001, 8, 921-932.

56. Eliasson, M.J.; Sampei, K.; Mandir, A.S.; Hurn, P.D.; Traystman, R.J.; Bao, J.; Pieper, A.; Wang, Z.Q.; Dawson, T.M.; Snyder, S.H.; et al. Poly(adp-ribose) polymerase gene disruption renders mice resistant to cerebral ischemia. Nat. Med. 1997, 3, 1089-1095.

57. Espinoza, L.A.; Smulson, M.E.; Chen, Z. Prolonged poly(adp-ribose) polymerase-1 activity regulates jp-8-induced sustained cytokine expression in alveolar macrophages. Free Radical Biol. Med. 2007, 42, 1430-1440.

58. Moroni, F.; Formentini, L.; Gerace, E.; Camaioni, E.; Pellegrini-Giampietro, D.E.; Chiarugi, A.; Pellicciari, R. Selective parp-2 inhibitors increase apoptosis in hippocampal slices but protect cortical cells in models of post-ischaemic brain damage. Br. J. Pharmacol 2009, 157, 854-862.

59. Banasik, M.; Stedeford, T.; Strosznajder, R.P. Natural inhibitors of poly(adp-ribose) polymerase-1. Mol. NeuroBiol. 2012, Submitted. 
60. Blenn, C.; Wyrsch, P.; Althaus, F.R. The ups and downs of tannins as inhibitors of poly(adpribose)glycohydrolase. Molecules 2011, 16, 1854-1877.

61. Slama, J.T.; Aboul-Ela, N.; Goli, D.M.; Cheesman, B.V.; Simmons, A.M.; Jacobson, M.K. Specific inhibition of poly(adp-ribose) glycohydrolase by adenosine diphosphate (hydroxymethyl)pyrrolidinediol. J. Med. Chem. 1995, 38, 389-393.

62. Slama, J.T.; Aboul-Ela, N.; Jacobson, M.K. Mechanism of inhibition of poly(adp-ribose) glycohydrolase by adenosine diphosphate (hydroxymethyl)pyrrolidinediol. J. Med. Chem. 1995, $38,4332-4336$.

63. Formentini, L.; Arapistas, P.; Pittelli, M.; Jacomelli, M.; Pitozzi, V.; Menichetti, S.; Romani, A.; Giovannelli, L.; Moroni, F.; Chiarugi, A. Mono-galloyl glucose derivatives are potent poly(adpribose) glycohydrolase (parg) inhibitors and partially reduce parp-1-dependent cell death. Br. J. Pharmacol. 2008, 155, 1235-1249.

64. Finch, K.E.; Knezevic, C.E.; Nottbohm, A.C.; Partlow, K.C.; Hergenrother, P.J. Selective small molecule inhibition of poly(adp-ribose) glycohydrolase (parg). ACS Chem Biol. 2012, 7, 563-570.

65. Steffen, J.D.; Coyle, D.L.; Damodaran, K.; Beroza, P.; Jacobson, M.K. Discovery and structure-activity relationships of modified salicylanilides as cell permeable inhibitors of poly(adp-ribose) glycohydrolase (parg). J. Med. Chem. 2011, 54, 5403-5413.

66. Wang, Z.Q.; Auer, B.; Stingl, L.; Berghammer, H.; Haidacher, D.; Schweiger, M.; Wagner, E.F. Mice lacking adprt and poly(adp-ribosyl)ation develop normally but are susceptible to skin disease. Genes Dev. 1995, 9, 509-520.

67. de Murcia, J.M.; Niedergang, C.; Trucco, C.; Ricoul, M.; Dutrillaux, B.; Mark, M.; Oliver, F.J.; Masson, M.; Dierich, A.; LeMeur, M.; et al. Requirement of poly(adp-ribose) polymerase in recovery from DNA damage in mice and in cells. Proc. Natl. Acad. Sci. USA 1997, 94, 7303-7307.

68. Le Rhun, Y.; Kirkland, J.B.; Shah, G.M. Cellular responses to DNA damage in the absence of poly(adp-ribose) polymerase. Biochem. Biophys. Res. Commun. 1998, 245, 1-10.

69. Wang, Z.Q.; Sting1, L.; Morrison, C.; Jantsch, M.; Los, M.; Schulze-Osthoff, K.; Wagner, E.F. Parp is important for genomic stability but dispensable in apoptosis. Genes Dev. 1997, 11, 2347-2358.

70. Menissier de Murcia, J.; Ricoul, M.; Tartier, L.; Niedergang, C.; Huber, A.; Dantzer, F.; Schreiber, V.; Ame, J.C.; Dierich, A.; LeMeur, M.; et al. Functional interaction between parp-1 and parp-2 in chromosome stability and embryonic development in mouse. EMBO J. 2003, 22, 2255-2263.

71. Dantzer, F.; Mark, M.; Quenet, D.; Scherthan, H.; Huber, A.; Liebe, B.; Monaco, L.; Chicheportiche, A.; Sassone-Corsi, P.; de Murcia, G.; et al. Poly(adp-ribose) polymerase-2 contributes to the fidelity of male meiosis i and spermiogenesis. Proc. Natl. Acad. Sci. USA 2006, 103, 14854-14859.

72. Bai, P.; Houten, S.M.; Huber, A.; Schreiber, V.; Watanabe, M.; Kiss, B.; de Murcia, G.; Auwerx, J.; Menissier-de Murcia, J. Poly(adp-ribose) polymerase-2 [corrected] controls adipocyte differentiation and adipose tissue function through the regulation of the activity of the retinoid $\mathrm{x}$ receptor/peroxisome proliferator-activated receptor-gamma [corrected] heterodimer. J. Biol. Chem. 2007, 282, 37738-37746. 
73. Yelamos, J.; Monreal, Y.; Saenz, L.; Aguado, E.; Schreiber, V.; Mota, R.; Fuente, T.; Minguela, A.; Parrilla, P.; de Murcia, G.; et al. Parp-2 deficiency affects the survival of cd4+cd8+ double-positive thymocytes. EMBO J. 2006, 25, 4350-4360.

74. Xi, H.; Kersh, G.J. Sustained early growth response gene 3 expression inhibits the survival of cd4/cd8 double-positive thymocytes. J. Immunol. 2004, 173, 340-348.

75. Oei, S.L.; Keil, C.; Ziegler, M. Poly(adp-ribosylation) and genomic stability. Biochem. Cell Biol. 2005, 83, 263-269.

76. Koh, D.W.; Lawler, A.M.; Poitras, M.F.; Sasaki, M.; Wattler, S.; Nehls, M.C.; Stoger, T.; Poirier, G.G.; Dawson, V.L.; Dawson, T.M. Failure to degrade poly(adp-ribose) causes increased sensitivity to cytotoxicity and early embryonic lethality. Proc. Natl. Acad. Sci. USA 2004, 101, 17699-17704.

77. Cortes, U.; Tong, W.M.; Coyle, D.L.; Meyer-Ficca, M.L.; Meyer, R.G.; Petrilli, V.; Herceg, Z.; Jacobson, E.L.; Jacobson, M.K.; Wang, Z.Q. Depletion of the 110-kilodalton isoform of poly(adp-ribose) glycohydrolase increases sensitivity to genotoxic and endotoxic stress in mice. Mol. Cell. Biol. 2004, 24, 7163-7178.

78. Meyer-Ficca, M.L.; Lonchar, J.; Credidio, C.; Ihara, M.; Li, Y.; Wang, Z.Q.; Meyer, R.G. Disruption of poly(adp-ribose) homeostasis affects spermiogenesis and sperm chromatin integrity in mice. Biol. Reprod. 2009, 81, 46-55.

79. Montgomery, M.K. Rna interference: Historical overview and significance. Meth. Mol. Biol. 2004, 265, 3-21.

80. Guo, S.; Kemphues, K.J. Par-1, a gene required for establishing polarity in c. Elegans embryos, encodes a putative ser/thr kinase that is asymmetrically distributed. Cell 1995, 81, 611-620.

81. Rocheleau, C.E.; Downs, W.D.; Lin, R.; Wittmann, C.; Bei, Y.; Cha, Y.H.; Ali, M.; Priess, J.R.; Mello, C.C. Wnt signaling and an apc-related gene specify endoderm in early c. Elegans embryos. Cell 1997, 90, 707-716.

82. Fire, A.; Xu, S.; Montgomery, M.K.; Kostas, S.A.; Driver, S.E.; Mello, C.C. Potent and specific genetic interference by double-stranded rna in caenorhabditis elegans. Nature 1998, 391, 806811.

83. Napoli, C.; Lemieux, C.; Jorgensen, R. Introduction of a chimeric chalcone synthase gene into petunia results in reversible co-suppression of homologous genes in trans. Plant. Cell. 1990, 2, 279-289.

84. Romano, N.; Macino, G. Quelling: Transient inactivation of gene expression in neurospora crassa by transformation with homologous sequences. Mol. Microbiol. 1992, 6, 3343-3353.

85. Hutvagner, G.; Zamore, P.D. Rnai: Nature abhors a double-strand. Curr. Opin. Genet. Dev. 2002, $12,225-232$.

86. Bernstein, E.; Caudy, A.A.; Hammond, S.M.; Hannon, G.J. Role for a bidentate ribonuclease in the initiation step of rna interference. Nature 2001, 409, 363-366.

87. Hammond, S.M.; Bernstein, E.; Beach, D.; Hannon, G.J. An rna-directed nuclease mediates posttranscriptional gene silencing in drosophila cells. Nature 2000, 404, 293-296.

88. Zamore, P.D.; Tuschl, T.; Sharp, P.A.; Bartel, D.P. Rnai: Double-stranded rna directs the atpdependent cleavage of mrna at 21 to 23 nucleotide intervals. Cell 2000, 101, 25-33. 
89. Elbashir, S.M.; Harborth, J.; Lendeckel, W.; Yalcin, A.; Weber, K.; Tuschl, T. Duplexes of 21-nucleotide rnas mediate rna interference in cultured mammalian cells. Nature 2001, 411, 494-498.

90. Robb, G.B.; Brown, K.M.; Khurana, J.; Rana, T.M. Specific and potent rnai in the nucleus of human cells. Nat. Struct. Mol. Biol. 2005, 12, 133-137.

91. Yu, J.Y.; DeRuiter, S.L.; Turner, D.L. Rna interference by expression of short-interfering rnas and hairpin rnas in mammalian cells. Proc. Natl. Acad. Sci. USA 2002, 99, 6047-6052.

92. Brummelkamp, T.R.; Bernards, R.; Agami, R. A system for stable expression of short interfering rnas in mammalian cells. Science 2002, 296, 550-553.

93. Rao, D.D.; Vorhies, J.S.; Senzer, N.; Nemunaitis, J. Sirna vs. Shrna: Similarities and differences. Adv. Drug Deliv. Rev. 2009, 61, 746-759.

94. Bartel, D.P. Micrornas: Genomics, biogenesis, mechanism, and function. Cell 2004, 116, 281-297.

95. Liu, J.; Rivas, F.V.; Wohlschlegel, J.; Yates, J.R., 3rd; Parker, R.; Hannon, G.J. A role for the p-body component gw182 in microrna function. Nat. Cell. Biol. 2005, 7, 1261-1266.

96. John, B.; Enright, A.J.; Aravin, A.; Tuschl, T.; Sander, C.; Marks, D.S. Human microrna targets. PLoS Biol. 2004, 2, e363.

97. Chang, T.C.; Yu, D.; Lee, Y.S.; Wentzel, E.A.; Arking, D.E.; West, K.M.; Dang, C.V.; Thomas-Tikhonenko, A.; Mendell, J.T. Widespread microrna repression by myc contributes to tumorigenesis. Nat. Genet. 2008, 40, 43-50.

98. Wang, Z.; Rao, D.D.; Senzer, N.; Nemunaitis, J. Rna interference and cancer therapy. Pharm. Res. 2011, 28, 2983-2995.

99. Seyhan, A.A. Rnai: A potential new class of therapeutic for human genetic disease. Hum. Genet. 2011, 130, 583-605.

100. Bora, R.S.; Gupta, D.; Mukkur, T.K.; Saini, K.S. Rna interference therapeutics for cancer: Challenges and opportunities (review). Mol. Med. Report. 2012, 6, 9-15.

101. Gan, L.; Anton, K.E.; Masterson, B.A.; Vincent, V.A.; Ye, S.; Gonzalez-Zulueta, M. Specific interference with gene expression and gene function mediated by long dsrna in neural cells. J. Neurosci. Meth. 2002, 121, 151-157.

102. Kameoka, M.; Nukuzuma, S.; Itaya, A.; Tanaka, Y.; Ota, K.; Ikuta, K.; Yoshihara, K. Rna interference directed against poly(adp-ribose) polymerase 1 efficiently suppresses human immunodeficiency virus type 1 replication in human cells. J. Virol. 2004, 78, 8931-8934.

103. Shah, R.G.; Ghodgaonkar, M.M.; Affar el, B.; Shah, G.M. DNA vector-based rnai approach for stable depletion of poly(adp-ribose) polymerase-1. Biochem. Biophys. Res. Commun. 2005, 331, 167-174.

104. Dykxhoorn, D.M.; Novina, C.D.; Sharp, P.A. Killing the messenger: Short rnas that silence gene expression. Nature reviews. Mol. Cell Biol. 2003, 4, 457-467.

105. Bai, P.; Canto, C.; Oudart, H.; Brunyanszki, A.; Cen, Y.; Thomas, C.; Yamamoto, H.; Huber, A.; Kiss, B.; Houtkooper, R.H.; et al. Parp-1 inhibition increases mitochondrial metabolism through sirt1 activation. Cell. Metab. 2011, 13, 461-468.

106. Tempera, I.; Deng, Z.; Atanasiu, C.; Chen, C.J.; D'Erme, M.; Lieberman, P.M. Regulation of epstein-barr virus orip replication by poly(adp-ribose) polymerase 1. J. Virol. 2010, 84, 4988-4997. 
107. Erdelyi, K.; Bai, P.; Kovacs, I.; Szabo, E.; Mocsar, G.; Kakuk, A.; Szabo, C.; Gergely, P.; Virag, L. Dual role of poly(adp-ribose) glycohydrolase in the regulation of cell death in oxidatively stressed a549 cells. Faseb J. 2009.

108. Erener, S.; Hesse, M.; Kostadinova, R.; Hottiger, M.O. Poly(adp-ribose)polymerase-1 (parp1) controls adipogenic gene expression and adipocyte function. Mol. Endocrinol. 2012, 26, 79-86.

109. Ambrose, H.E.; Papadopoulou, V.; Beswick, R.W.; Wagner, S.D. Poly-(adp-ribose) polymerase1 (parp-1) binds in a sequence-specific manner at the bcl-6 locus and contributes to the regulation of bcl-6 transcription. Oncogene 2007, 26, 6244-6252.

110. Huang, X.; Dong, Y.; Bey, E.A.; Kilgore, J.A.; Bair, J.S.; Li, L.S.; Patel, M.; Parkinson, E.I.; Wang, Y.; Williams, N.S.; et al. An nqo1 substrate with potent antitumor activity that selectively kills by parp1-induced programmed necrosis. Cancer Res. 2012, 72, 3038-3047.

111. Fisher, A.E.; Hochegger, H.; Takeda, S.; Caldecott, K.W. Poly(adp-ribose) polymerase 1 accelerates single-strand break repair in concert with poly(adp-ribose) glycohydrolase. Mol. Cell. Biol. 2007, 27, 5597-5605.

112. Strom, C.E.; Johansson, F.; Uhlen, M.; Szigyarto, C.A.; Erixon, K.; Helleday, T. Poly (adpribose) polymerase (parp) is not involved in base excision repair but parp inhibition traps a single-strand intermediate. Nucleic Acids Res. 2011, 39, 3166-3175.

113. Hegan, D.C.; Lu, Y.; Stachelek, G.C.; Crosby, M.E.; Bindra, R.S.; Glazer, P.M. Inhibition of poly(adp-ribose) polymerase down-regulates brca1 and rad51 in a pathway mediated by e2f4 and p130. Proc. Natl. Acad. Sci. USA 2010, 107, 2201-2206.

114. Modis, K.; Gero, D.; Erdelyi, K.; Szoleczky, P.; DeWitt, D.; Szabo, C. Cellular bioenergetics is regulated by parp1 under resting conditions and during oxidative stress. Biochem. Pharmacol. 2012, 83, 633-643.

115. Mathieu, J.; Flexor, M.; Lanotte, M.; Besancon, F. A parp-1/jnk1 cascade participates in the synergistic apoptotic effect of tnfalpha and all-trans retinoic acid in apl cells. Oncogene 2008, 27, 3361-3370.

116. Kandan-Kulangara, F.; Shah, R.G.; Affar el, B.; Shah, G.M. Persistence of different forms of transient rnai during apoptosis in mammalian cells. PloS one 2010, 5, e12263.

117. Cimadamore, F.; Curchoe, C.L.; Alderson, N.; Scott, F.; Salvesen, G.; Terskikh, A.V. Nicotinamide rescues human embryonic stem cell-derived neuroectoderm from parthanatic cell death. Stem Cells 2009, 27, 1772-1781.

118. Ding, W.; Liu, W.; Cooper, K.L.; Qin, X.J.; de Souza Bergo, P.L.; Hudson, L.G.; Liu, K.J. Inhibition of poly(adp-ribose) polymerase-1 by arsenite interferes with repair of oxidative DNA damage. J. Biol. Chem. 2009, 284, 6809-6817.

119. Qin, X.J.; Hudson, L.G.; Liu, W.; Timmins, G.S.; Liu, K.J. Low concentration of arsenite exacerbates uvr-induced DNA strand breaks by inhibiting parp-1 activity. Toxicol. Appl. Pharmacol 2008, 232, 41-50.

120. Zhang, N.; Chen, Y.; Jiang, R.; Li, E.; Chen, X.; Xi, Z.; Guo, Y.; Liu, X.; Zhou, Y.; Che, Y.; et al. Parp and rip 1 are required for autophagy induced by 11'-deoxyverticillin a, which precedes caspase-dependent apoptosis. Autophagy 2011, 7, 598-612. 
121. Vernole, P.; Muzi, A.; Volpi, A.; Terrinoni, A.; Dorio, A.S.; Tentori, L.; Shah, G.M.; Graziani, G. Common fragile sites in colon cancer cell lines: Role of mismatch repair, rad51 and poly(adpribose) polymerase-1. Mutation Res. 2011, 712, 40-48.

122. Cohausz, O.; Blenn, C.; Malanga, M.; Althaus, F.R. The roles of poly(adp-ribose)-metabolizing enzymes in alkylation-induced cell death. Cell. Mol. Life Sci. 2008, 65, 644-655.

123. Ouararhni, K.; Hadj-Slimane, R.; Ait-Si-Ali, S.; Robin, P.; Mietton, F.; Harel-Bellan, A.; Dimitrov, S.; Hamiche, A. The histone variant mh2a1.1 interferes with transcription by down-regulating parp-1 enzymatic activity. Genes Dev. 2006, 20, 3324-3336.

124. Ghosh, U.; Das, N.; Bhattacharyya, N.P. Inhibition of telomerase activity by reduction of poly(adp-ribosyl)ation of tert and tep1/tp1 expression in hela cells with knocked down poly(adpribose) polymerase-1 (parp-1) gene. Mutation Res. 2007, 615, 66-74.

125. Muthumani, K.; Choo, A.Y.; Zong, W.X.; Madesh, M.; Hwang, D.S.; Premkumar, A.; Thieu, K.P.; Emmanuel, J.; Kumar, S.; Thompson, C.B.; et al. The hiv-1 vpr and glucocorticoid receptor complex is a gain-of-function interaction that prevents the nuclear localization of parp-1. Nat. Cell. Biol. 2006, 8, 170-179.

126. Chang, P.; Coughlin, M.; Mitchison, T.J. Tankyrase-1 polymerization of poly(adp-ribose) is required for spindle structure and function. Nat. Cell. Biol. 2005, 7, 1133-1139.

127. Cohausz, O.; Althaus, F.R. Role of parp-1 and parp-2 in the expression of apoptosis-regulating genes in hela cells. Cell. Biol. Toxicol. 2009, 25, 379-391.

128. Beneke, S.; Cohausz, O.; Malanga, M.; Boukamp, P.; Althaus, F.; Burkle, A. Rapid regulation of telomere length is mediated by poly(adp-ribose) polymerase-1. Nucleic Acids Res. 2008, 36, 6309-6317.

129. Szanto, A.; Hellebrand, E.E.; Bognar, Z.; Tucsek, Z.; Szabo, A.; Gallyas, F. Jr.; Sumegi, B.; Varbiro, G. Parp-1 inhibition-induced activation of pi-3-kinase-akt pathway promotes resistance to taxol. Biochem. Pharmacol. 2009, 77, 1348-1357.

130. Byun, J.Y.; Kim, M.J.; Eum, D.Y.; Yoon, C.H.; Seo, W.D.; Park, K.H.; Hyun, J.W.; Lee, Y.S.; Lee, J.S.; Yoon, M.Y.; et al. Reactive oxygen species-dependent activation of bax and poly(adpribose) polymerase-1 is required for mitochondrial cell death induced by triterpenoid pristimerin in human cervical cancer cells. Mol. Pharmacol 2009, 76, 734-744.

131. Pang, J.; Gong, H.; Xi, C.; Fan, W.; Dai, Y.; Zhang, T.M. Poly(adp-ribose) polymerase 1 is involved in glucose toxicity through sirt1 modulation in hepg2 hepatocytes. J. Cell. Biochem 2011, 112, 299-306.

132. Mathews, M.T.; Berk, B.C. Parp-1 inhibition prevents oxidative and nitrosative stress-induced endothelial cell death via transactivation of the vegf receptor 2. Arterioscler Thromb Vasc Biol. 2008, 28, 711-717.

133. Park, M.T.; Kim, M.J.; Kang, Y.H.; Choi, S.Y.; Lee, J.H.; Choi, J.A.; Kang, C.M.; Cho, C.K.; Kang, S.; Bae, S.; et al. Phytosphingosine in combination with ionizing radiation enhances apoptotic cell death in radiation-resistant cancer cells through ros-dependent and -independent aif release. Blood 2005, 105, 1724-1733. 
134. Frizzell, K.M.; Gamble, M.J.; Berrocal, J.G.; Zhang, T.; Krishnakumar, R.; Cen, Y.; Sauve, A.A.; Kraus, W.L. Global analysis of transcriptional regulation by poly(adp-ribose) polymerase-1 and poly(adp-ribose) glycohydrolase in mcf-7 human breast cancer cells. J. Biol. Chem. 2009, 284, 33926-33938.

135. Wyrsch, P.; Blenn, C.; Bader, J.; Althaus, F.R. Cell death and autophagy under oxidative stress: Roles of poly(adp-ribose)polymerases and ca2+. Mol. Cell. Biol. 2012.

136. Ariumi, Y.; Turelli, P.; Masutani, M.; Trono, D. DNA damage sensors atm, atr, DNA-pkcs, and parp-1 are dispensable for human immunodeficiency virus type 1 integration. J. Virol. 2005, 79, 2973-2978.

137. Lin, Y.; Tang, X.; Zhu, Y.; Shu, T.; Han, X. Identification of parp-1 as one of the transcription factors binding to the repressor element in the promoter region of cox-2. Arch. Biochem. Biophys. 2011, 505, 123-129.

138. Kondo, K.; Obitsu, S.; Ohta, S.; Matsunami, K.; Otsuka, H.; Teshima, R. Poly(adp-ribose) polymerase (parp)-1-independent apoptosis-inducing factor (aif) release and cell death are induced by eleostearic acid and blocked by alpha-tocopherol and mek inhibition. J. Biol. Chem. 2010, 285, 13079-13091.

139. Woodhouse, B.C.; Dianova, I.I.; Parsons, J.L.; Dianov, G.L. Poly(adp-ribose) polymerase-1 modulates DNA repair capacity and prevents formation of DNA double strand breaks. DNA Repair 2008, 7, 932-940.

140. Diaz-Hernandez, J.I.; Moncada, S.; Bolanos, J.P.; Almeida, A. Poly(adp-ribose) polymerase-1 protects neurons against apoptosis induced by oxidative stress. Cell. Death Differ. 2007, 14, 1211-1221.

141. Kitamura, T.; Sekimata, M.; Kikuchi, S.; Homma, Y. Involvement of poly(adp-ribose) polymerase 1 in erbb2 expression in rheumatoid synovial cells. Am. J. Physiol. Cell. Physiol. 2005, 289, C82-88.

142. Garcia, S.; Bodano, A.; Pablos, J.L.; Gomez-Reino, J.J.; Conde, C. Poly(adp-ribose) polymerase inhibition reduces tumor necrosis factor-induced inflammatory response in rheumatoid synovial fibroblasts. Ann. Rheum. Dis. 2008, 67, 631-637.

143. Huang, D.; Wang, Y.; Wang, L.; Zhang, F.; Deng, S.; Wang, R.; Zhang, Y.; Huang, K. Poly(adpribose) polymerase 1 is indispensable for transforming growth factor-beta induced smad3 activation in vascular smooth muscle cell. PloS One 2011, 6, e27123.

144. Lapucci, A.; Pittelli, M.; Rapizzi, E.; Felici, R.; Moroni, F.; Chiarugi, A. Poly(adp-ribose) polymerase-1 is a nuclear epigenetic regulator of mitochondrial DNA repair and transcription. Mol. Pharmacol. 2011, 79, 932-940.

145. Bryant, H.E.; Schultz, N.; Thomas, H.D.; Parker, K.M.; Flower, D.; Lopez, E.; Kyle, S.; Meuth, M.; Curtin, N.J.; Helleday, T. Specific killing of brca2-deficient tumours with inhibitors of poly(adp-ribose) polymerase. Nature 2005, 434, 913-917.

146. Racz, B.; Hanto, K.; Tapodi, A.; Solti, I.; Kalman, N.; Jakus, P.; Kovacs, K.; Debreceni, B.; Gallyas, F. Jr.; Sumegi, B. Regulation of mkp-1 expression and mapk activation by parp-1 in oxidative stress: A new mechanism for the cytoplasmic effect of parp-1 activation. Free Radical Biol. Med. 2010, 49, 1978-1988. 
147. Boehler, C.; Gauthier, L.R.; Mortusewicz, O.; Biard, D.S.; Saliou, J.M.; Bresson, A.; SanglierCianferani, S.; Smith, S.; Schreiber, V.; Boussin, F.; et al. Poly(adp-ribose) polymerase 3 (parp3), a newcomer in cellular response to DNA damage and mitotic progression. Proc. Natl. Acad. Sci. USA 2011, 108, 2783-2788.

148. Loseva, O.; Jemth, A.S.; Bryant, H.E.; Schuler, H.; Lehtio, L.; Karlberg, T.; Helleday, T. Parp-3 is a mono-adp-ribosylase that activates parp-1 in the absence of DNA. J. Biol. Chem. 2010, 285, 8054-8060.

149. Chang, W.; Dynek, J.N.; Smith, S. Numa is a major acceptor of poly(adp-ribosyl)ation by tankyrase 1 in mitosis. Biochem. J 2005, 391, 177-184.

150. Diani-Moore, S.; Ram, P.; Li, X.; Mondal, P.; Youn, D.Y.; Sauve, A.A.; Rifkind, A.B. Identification of the aryl hydrocarbon receptor target gene tiparp as a mediator of suppression of hepatic gluconeogenesis by 2,3,7,8-tetrachlorodibenzo-p-dioxin and of nicotinamide as a corrective agent for this effect. J. Biol. Chem. 2010, 285, 38801-38810.

151. Di Paola, S.; Micaroni, M.; Di Tullio, G.; Buccione, R.; Di Girolamo, M. Parp16/artd15 is a novel endoplasmic-reticulum-associated mono-adp-ribosyltransferase that interacts with, and modifies karyopherin-ss1. PloS one 2012, 7, e37352.

152. Hung, C.F.; Cheng, T.L.; Wu, R.H.; Teng, C.F.; Chang, W.T. A novel bidirectional expression system for simultaneous expression of both the protein-coding genes and short hairpin rnas in mammalian cells. Biochem. Biophys. Res. Commun. 2006, 339, 1035-1042.

153. Bai, P.; Canto, C.; Brunyanszki, A.; Huber, A.; Szanto, M.; Cen, Y.; Yamamoto, H.; Houten, S.M.; Kiss, B.; Oudart, H.; et al. Parp-2 regulates sirt1 expression and whole-body energy expenditure. Cell Metab. 2011, 13, 450-460.

154. Szanto, M.; Rutkai, I.; Hegedus, C.; Czikora, A.; Rozsahegyi, M.; Kiss, B.; Virag, L.; Gergely, P.; Toth, A.; Bai, P. Poly(adp-ribose) polymerase-2 depletion reduces doxorubicin-induced damage through sirt1 induction. Cardiovasc. Res. 2011, 92, 430-438.

155. Gravel, C.; Stergiou, L.; Gagnon, S.N.; Desnoyers, S. The c. Elegans gene pme-5: Molecular cloning and role in the DNA-damage response of a tankyrase orthologue. DNA Repair 2004, 3, 171-182.

156. St-Laurent, J.F.; Gagnon, S.N.; Dequen, F.; Hardy, I.; Desnoyers, S. Altered DNA damage response in caenorhabditis elegans with impaired poly(adp-ribose) glycohydrolases genes expression. DNA Repair 2007, 6, 329-343.

157. Boamah, E.K.; Kotova, E.; Garabedian, M.; Jarnik, M.; Tulin, A.V. Poly(adp-ribose) polymerase 1 (parp-1) regulates ribosomal biogenesis in drosophila nucleoli. PLoS Genet. 2012, 8, e1002442.

158. Tulin, A.; Naumova, N.M.; Menon, A.K.; Spradling, A.C. Drosophila poly(adp-ribose) glycohydrolase mediates chromatin structure and sir2-dependent silencing. Genetics 2006, 172, 363-371.

159. Popoff, I.; Jijon, H.; Monia, B.; Tavernini, M.; Ma, M.; McKay, R.; Madsen, K. Antisense oligonucleotides to poly(adp-ribose) polymerase-2 ameliorate colitis in interleukin-10-deficient mice. J. Pharmacol. Exp. Ther. 2002, 303, 1145-1154. 
160. Goldberg, M.S.; Xing, D.; Ren, Y.; Orsulic, S.; Bhatia, S.N.; Sharp, P.A. Nanoparticle-mediated delivery of sirna targeting parp1 extends survival of mice bearing tumors derived from brca1deficient ovarian cancer cells. Proc. Natl. Acad. Sci. USA 2011, 108, 745-750.

161. De Block, M.; Verduyn, C.; De Brouwer, D.; Cornelissen, M. Poly(adp-ribose) polymerase in plants affects energy homeostasis, cell death and stress tolerance. Plant. J Cell Mol. Biol. 2005, 41, 95-106.

162. Vanderauwera, S.; De Block, M.; Van de Steene, N.; van de Cotte, B.; Metzlaff, M.; Van Breusegem, F. Silencing of poly(adp-ribose) polymerase in plants alters abiotic stress signal transduction. Proc. Natl. Acad. Sci. USA 2007, 104, 15150-15155.

163. Blenn, C.; Althaus, F.R.; Malanga, M. Poly(adp-ribose) glycohydrolase silencing protects against h2o2-induced cell death. Biochem. J 2006, 396, 419-429.

164. Feng, X.; Zhou, Y.; Proctor, A.M.; Hopkins, M.M.; Liu, M.; Koh, D.W. Silencing of apoptosisinducing factor and poly(adp-ribose) glycohydrolase reveals novel roles in breast cancer cell death after chemotherapy. Mol. Cancer 2012, 11, 48.

165. Andrabi, S.A.; Kim, N.S.; Yu, S.W.; Wang, H.; Koh, D.W.; Sasaki, M.; Klaus, J.A.; Otsuka, T.; Zhang, Z.; Koehler, R.C.; et al. Poly(adp-ribose) (par) polymer is a death signal. Proc. Natl Acad Sci. USA 2006, 103, 18308-18313.

166. Ame, J.C.; Fouquerel, E.; Gauthier, L.R.; Biard, D.; Boussin, F.D.; Dantzer, F.; de Murcia, G.; Schreiber, V. Radiation-induced mitotic catastrophe in parg-deficient cells. J. Cell Sci. 2009, 122, 1990-2002.

167. Norberg, E.; Gogvadze, V.; Ott, M.; Horn, M.; Uhlen, P.; Orrenius, S.; Zhivotovsky, B. An increase in intracellular ca2 + is required for the activation of mitochondrial calpain to release aif during cell death. Cell. Death Differ. 2008, 15, 1857-1864.

168. Naziroglu, M. Trpm2 cation channels, oxidative stress and neurological diseases: Where are we now? Neurochemical. Res. 2011, 36, 355-366.

169. Perraud, A.L.; Fleig, A.; Dunn, C.A.; Bagley, L.A.; Launay, P.; Schmitz, C.; Stokes, A.J.; Zhu, Q.; Bessman, M.J.; Penner, R.; et al. Adp-ribose gating of the calcium-permeable ltrpc2 channel revealed by nudix motif homology. Nature 2001, 411, 595-599.

170. Toth, B.; Csanady, L. Identification of direct and indirect effectors of the transient receptor potential melastatin 2 (trpm2) cation channel. J. Biol. Chem. 2010, 285, 30091-30102.

171. Buelow, B.; Song, Y.; Scharenberg, A.M. The poly(adp-ribose) polymerase parp-1 is required for oxidative stress-induced trpm2 activation in lymphocytes. J. Biol. Chem. 2008, 283, 24571-24583.

172. Huang, H.Y.; Cai, J.F.; Liu, Q.C.; Hu, G.H.; Xia, B.; Mao, J.Y.; Wu, D.S.; Liu, J.J.; Zhuang, Z.X. Role of poly(adp-ribose) glycohydrolase in the regulation of cell fate in response to benzo(a)pyrene. Exp. cell Res. 2012, 318, 682-690.

173. Biard, D.S. Untangling the relationships between DNA repair pathways by silencing more than 20 DNA repair genes in human stable clones. Nucleic Acids Res. 2007, 35, 3535-3550.

174. Li, Q.; Li, M.; Wang, Y.L.; Fauzee, N.J.; Yang, Y.; Pan, J.; Yang, L.; Lazar, A. Rna interference of parg could inhibit the metastatic potency of colon carcinoma cells via pi3-kinase/akt pathway. Cell. Physiol. Biochem. 2012, 29, 361-372. 
175. Pan, J.; Fauzee, N.J.; Wang, Y.L.; Sheng, Y.T.; Tang, Y.; Wang, J.Q.; Wu, W.Q.; Yan, J.X.; Xu, J. Effect of silencing parg in human colon carcinoma lovo cells on the ability of huvec migration and proliferation. Cancer Gene Ther. 2012, Submitted.

176. Fathers, C.; Drayton, R.M.; Solovieva, S.; Bryant, H.E. Inhibition of poly(adp-ribose) glycohydrolase (parg) specifically kills brca2-deficient tumor cells. Cell. Cycle 2012, 11, 990-997.

177. Tang, J.B.; Svilar, D.; Trivedi, R.N.; Wang, X.H.; Goellner, E.M.; Moore, B.; Hamilton, R.L.; Banze, L.A.; Brown, A.R.; Sobol, R.W. N-methylpurine DNA glycosylase and DNA polymerase beta modulate ber inhibitor potentiation of glioma cells to temozolomide. Neuro Oncol. 2011, 13, 471-486.

178. Rapizzi, E.; Fossati, S.; Moroni, F.; Chiarugi, A. Inhibition of poly(adp-ribose) glycohydrolase by gallotannin selectively up-regulates expression of proinflammatory genes. Mol. Pharmacol. 2004, 66, 890-898.

(C) 2012 by the authors; licensee MDPI, Basel, Switzerland. This article is an open access article distributed under the terms and conditions of the Creative Commons Attribution license (http://creativecommons.org/licenses/by/3.0/). 